\title{
Undang-Undang Sumatera Barat (Minangkabau) Tahun 1837-1862
}

\author{
Yulianti, Amung Ahmad SM, Fathia Lestari \\ Fakultas Adab dan Humaniora, Universitas Islam Negeri Sunan Gunung \\ Djati Bandung \\ Email: yyulianti778@gmail.com
}

\begin{abstract}
This article discusses the constitution (undang-undang) of West Sumatra. The Minangkabau people constitute the Matrilineal community. Their customs and culture place the women as the inheritors of inheritance and kinship. Nevertheless, the role of men who actively play roles in religious and political spheres is still significant. Seen from their economy, the Minangkabau indigenous people have a wealth of fertile land so that the majority of the community's work is farming various plants such as coffee, spices, rice etc. The progress of the community is not only in the economic field but also the development of Islam. The spread of Islam continues to grow and the Islam has been a popular religion among the Minangkabau people. The community also has a legal order written in an Act, which was written in Minangkabau in 1837 precisely after the Padri war and the Dutch rule in the Minangkabau land. Dutch Residents (Heinmers) ordered community leaders to write a customary law into the West Sumatra Act, the enactment of this West Sumatra Law until 1862 because when the Dutch set new regulations on the Minangkabau community, namely stelsel culture so that people followed all the new rules. The West Sumatra Law is divided into three parts: the Adat Law in Nagari, the Murder Case Law, and the Syara Companding Adat Law.
\end{abstract}

Keywords: Minangkabau Society, customary law, local act. 


\section{Pendahuluan}

Menurut Ibrahim Dt. Sanggoeno Dirajo Minangkabau (Minang) adalah kelompok etnis di Indonesia yang berbahasa melayu dan menjunjung adat Minangkabau. Prinsip adat Minangkabau tertuang singkat dalam pernyataan "Adat bersandi syarak, syarak bersandi Kitabullah" (adat bersendikan hukum, hukum bersendikan Al-Qur'an) yang berarti adat berlandaskan ajaran Islam. Jika tidak beragama Islam berarti seorang itu tidaklah merupakan bagian dalam masyarakat Minangkabau, itulah pemaknaan dari pernyataan tersebut.

Matrilineal merupakan salah satu aspek utama dalam mendefinisikan identitas masyarakat Minangkabau. Adat dan budaya mereka menempatkan pihak perempuan bertindak sebagai pewaris harta pusaka dan kekerabatan. Garis keturunan dirujuk kepada ibu yang dikenal dengan Samandeh ${ }^{1}$ (seibu), sedangkan ayah mereka disebut oleh masyarakat dengan sebutan Sumando $^{2}$ (ipar) dan diperlakukan sebagai tamu dalam keluarga. ${ }^{3}$

Minangkabau juga kaya akan tradisi dan kebudayaan, khususnya dalam hal hukum, Hukum adat berkembang dan maju terus, keputusankeputusan adat menimbulkan hukum adat. Mengingat hukum adat sebagai kristalisasi budaya bangsa Indonesia, sehingga perlu adanya upaya untuk merivitalisasi hukum Adat, dan menjadikannya sebagai bagian dari sumber pembentukan hukum nasional. Berkenaan dengan pembentukan hukum nasional, hukum itu harus peka terhadap perkembangan masyarakat dan bahwa hukum itu harus disesuaikan dan menyesuaikan diri dengan keadaan, Hukum adat juga dapat dijadikan sebagai sumber hukum undang-undang, Hukum adat merupakan hukum yang tidak dikodifikasi di kalangan bangsa Indonesia. ${ }^{4}$

\footnotetext{
${ }^{1}$ Menurut Kamus Minagkabau-Indonesia Samandeh adalah garis keturunan se ibu, anggota keluarga berasal dari satu Rumah Gadang dan dari saudara seibu. (https://id.glosbe.com/ diakses pada Tanggal 15 Desember 2019. Pukul: 13.00. WIB).

${ }^{2}$ Menurut Kamus Minagkabau-Indonesia Sumando adalah istilah yang diberikan kepada seorang lelaki Minang ketika telah menikah. Sumando juga berarti posisi atau kedudukan seorang lelaki minang ketika berada di rumah/kampung istrinya. (https://id.glosbe.com/ diakses pada Tanggal 15 Desember 2019. Pukul: 13.00. WIB).

${ }^{3}$ Maryelliwati, Sastra Minanggkabau Dan Penciptaan Sebuah Karya (Padang: Institut Seni Indonesia Padang Panjang, 2016). 5

${ }^{4}$ Lastuti Abubakar, "Revitalisasi Hukum Adat Sebagai Sumber Hukum Dalam Membangun Sistem Hukum Indonesia,” Dinamika Hukum 13, no. 2 (2013). 322
} 
Mengingat hukum adat adalah hukum yang hidup karena merupakan penjelmaan perasaan hukum yang nyata dari rakyat. Sesuai fitrahnya sendiri, hukum adat terus menerus dalam keadaan tumbuh dan berkembang seperti hidup itu sendiri, hukum yang mencerminkan kepribadian dan jiwa bangsa, maka diyakini bahwa sebagian pranata hukum adat sebagian tentu masih relevan menjadi bahan dalam membentuk sistem hukum Indonesia. Oleh karena itu masyarakat Minangkaabau mempunyai hukum adat yang kemudian dijadikan sebagai undang-undang yang mengatur dalam berbagai hal kehidupan yaitu dirumuskan dalam Undang-undang Sumatera Barat $1837-1862 .^{5}$

Undang-undang Sumatera Barat Tahun 1837-1862, Undang-undang ini berasal dari hukum adat yang berlaku di masyarakat Minangkabau pada tahun 1837-1862 didalam naskah Undang-undang Sumatera Barat Tahun 1837-1862 dipaparkan terdapat 3 pemaparan secara umum mengenai (Undang-undang dalam Negeri, Perkara pembunuhan, dan adat bersanding syara) kemudian dari 3 point ini terdapat uraian-uraian kembali. Undangundang ini ditulis atas perintah Belanda pada tahun 1837-1862 dengan bentuk tulisan latin dan berbahasa Melayu, adapun latar belakang penulisan naskah ini yakni, ketika pemerintah Belanda mengambil kesempatan yang baik, dengan usaha ikut terlibat dalam perang saudara di daerah Minangkabau antara kaum Padri melawan kaum Adat. Pemerintahan Belanda memberi bantuan untuk kaum elite pribumi yang terjepit melawan kaum padri, bertujuan untuk memurnikan ajaran agama Islam dengan memperbaiki adat dan kebiasaan yang bertentangan dengan Al-Qur'An dan Sunah Nabi.

\section{Metode}

Langkah-langkah yang digunakan dalam penelitian ini yaitu melalui metode sejarah dan menggunakan penelitian deskriptif analisis, Sebagai cara untuk memaparkan kondisi transportasi haji masa Kolonial, maka langkahlangkah penelitiannya sebagai berikut:

Pertama, tahap heuristik Pada tahapan ini penulis mencoba melacak atau mencari sumber yang memiliki korelasi dengan judul penelitian. Sebab tanpa

\footnotetext{
${ }^{5}$ Abubakar. 322
} 
sumber, tulisan yang dihasilkan itu bukan merupakan karya sejarah. Bila suatu karya yang menggambarkan tentang kehidupan masa lalu tanpa didasari oleh sumber. ${ }^{6}$ Oleh karena itu Pada tahap ini, kegiatan yang dilakukan adalah proses pencarian, pelacakan, dan pengumpulan sumbersumber yang berkenaan dengan topik yang dibahas. dari uraian diatas mengenai heuristik, penulis menemukan berbagai sumber baik sumber primer maupun sumber sekunder yang dapat dijadikan rujukan dalam proses penyusunan skripsi adalah sebagai berikut:

1. Sumber data primer berupa manuskrip naskah, kemudian yang penulis dapatkan dari koleksi Perpustakaan Digital Singapore Manuskrip Naskah Undang-undang Sumatera Barat: Digitale Bibliothek der SBB. 1976. https://eresources.nlb.gov.sg/printheritage/index.htm. Di akses pada Tanggal 11-02-2019. Pukul. 14:00. WIB.

2. Sumber data sekunder berupa buku adalah sebagai berikut:

a. Maryelliwati. Sastra Minangkabau dan Penciptaan Sebuah Karya. (Sumatera Barat: INSTITUT SENI INDONESIA PADANG PANJANG. 2016).

b. Darwis, Yuliandre. Sejarah Perkembangan Pers Minangkabau. (Jakarta: PT Gramedia Pustaka Utama. 2013

Tahap kedua yaitu kritik merupakan tahap mengkritisi sumber yang sudah didapatkan. Dalam tahapan ini yang dilakukan adalah menentukan kredibilitas dan otentisitas sebuah sumber baik itu naskah atau dokumen yang nantinya akan ditentukan tingkat validitasnya dilihat dari teks dan nilainilai isi. Tahapan kritik ini dibagi menjadi dua yaitu kritik intern dan ekstern.

Sumber Primer.

1. Naskah Undang-undang Sumatera Barat pada Abad ke-19 naskah ini penulis dapatkan melalui situs Perpustakaan Singapore (SG) Keadaan Manuskrip Naskah masih bagus dan lumayan jelas sehingga penulis bisa membacanya kemudian naskah ini terdiri dari 33 halaman dan memiliki Cover berwarna coklat, dan bagian depannya bermotif bulat tidak beraturan dibalut dengan warna kuning, naskah ini ditulis menggunakan tulisan latin dan berbahasa Melayu, tetapi kemudian naskah ini diterbitkan dalam bentuk manuskrip oleh Digitale Bibliothek der SBB pada tahun 1906.

${ }^{6}$ Abd Raahman Hamid, Pengantar Ilmu Sejarah (Yogyakarta: Ombak, 2011). 12 
Buku.

Wulansari, Dewi. 2014. Hukum Adat Indonesia. Bandung: PT. Refika Aditama. Buku ini membahas mengenai apa istilah hukum adat, hukum adat dan adat dan hukum kebiasaan kemudian wujud hukum adat tersebut, bagaimana corak dan sistem hukum adat sebagai sumber pengenal hukum adat hingga membahas mengenai hukum adat dalam peraturan perundangundangan Hindia Belanda dan Republik Indonesia.buku ini memiliki hubungan dengan apa yang penulis teliti.

Sumber Sekunder.

A.A. Nafis, 1984. Alam Terkembang Jadi Guru: Adat dan Kebudayaan Minangkabau. cet. I. Jakarta: Temprint. Buku ini menjelaskan mengenai adat istiadat serta kebudayaan pada masyarakat Minangkabau.

Ketiga, interprestasi adalah proses untuk menyinkronkan fakta-fakta yang telah di analisis dari tahapan sebelumnya yaitu kritik. Dalam konteks ini Sejarawan Sartono Kartodirdjo mengembangkan pendekatan multidimensional dalam studi sejarah, pada tahap interpretasi inilah ilmu sejarah tidak berdiri sendiri, maka dari itu diperlukan sejumlah konsep dan pendekatan teoritis dari ilmu-ilmu lain, terutama ilmu hukum, sehingga konstruksi masa lalu lebih kritis dan analitis. ${ }^{7}$

Hukum adat Minangkabau diartikan sebagai, peraturan yang mengatur tata cara pergaulan antara masyarakat dengan pergaulan serta antara perorangan sesamanya. Menurut bahasa juga bahwa adat adalah kata yang lazim dipakai tanpa membedakan mana yang dijalankan dengan mempunyai sangsi yang disebut hukum adat dan yang tidak mempunyai sangsi yang disebut hukum adat dan yang tidak mempunyai sangsi yang disebut adat. Kata adat ini disamping dipergunakan untuk hal yang baik, tak hanya itu dipergunakan juga sebagai suatu yang harus dijauhi oleh seseorang. ${ }^{8}$

Keempat, Historiografi merupakan tahapan terakhir dalam metode penelitian. Dari sumber-sumber yang penulis dapatkan serta hasil interpretasi mengenai sumber yang kemudian penulis gabungkan menjadi sebuah tulisan. Menulis kisah sejarah bukan sekedar menyusun dan merangkai fakta-fakta

\footnotetext{
${ }^{7}$ Hamid. 51

${ }^{8}$ Niko Ferlan, "Konsep Nikah Sepupu Dalam Presfectif Adat Minangkabau Dan HukumIslam Studi Kasus Luhak Agam Lubuk Basung Sumatera Barat (Antara Syari'ah Dan Adat)" (UIN Sultan Syarif Kasir Riau, 2016). 38
} 
hasil penelitian, melainkan juga menyampaikan satu pemikiran melalui interpretasi sejarah yang berdasarkan fakta-fakta hasil penelitian. Untuk itu, menulis sejarah memerlukan kecakapan dan kemahiran. Historiografi merupakan rekaman tentang segala sesuatu yang dicatat sebagai bahan perjalanan tentang perilaku yang baik. Sesudah menentukan judul, pengumpulan bahan-bahan sumber serta melakukan kritik dan seleksi, maka mulailah menulis kisah sejarah.

\section{Pembahasan}

\section{Sumatera Barat sebelum Abad ke-19}

\section{Wilayah Minangkabau}

Secara Geografis, bahwa wilayah Minangkabau ini terbagi atas wilayah inti yang disebut Darek atau wilayah perkembangannya yang disebut rantau dan pesisir. Inilah alam Minangkabau, dimulai dengan mendaratnya leluhur pertama di Gunung Merapi, yang saat itu dikelilingi air. Sejarah awal Minangkabau pun berawal dari air sebelum surut, sebelum permukaan bumi naik tajam, sebelum penghuninya bertambah. Ketika air surut, kediaman-kediaman baru dibangun, dan pada akhirnya kawasan dibagi menjadi 3 luhak ${ }^{9}$, maka dari itu di bawah ini adalah wilayah-wilayah inti Minangkabau yaitu Darek, Pesisir, dan Rantau. Berikut adalah penjelasannya:

Darek merupakan Tempat yang berlokasi di dataran tinggi yang dikitari oleh tiga gunung, yaitu Gunung Merapi, Gunung Sago dan Gunung Sunggalang. Masyarakat Minangkabau juga meyakini bahwa sejarah etnis mereka ini bermula dari pemukiman di lereng bagian selatan Gunung Merapi, sebuah Volkano pada gugusan Gunung Merapi. ${ }^{10}$ Daerah ini dibagi menjadi 3 luhak ${ }^{11}$ yaitu Luhak Tanah Data sebagai luhak tanah nan tuo,

${ }^{9}$ Luhak adalah kawasan inti Alam Minangkabau (asal orang Minang), wilayahnya terletak di dataran tinggi pedalaman Minangkabau yang membentang dari utara ke selatan dengan ketinggian berkisar antara 1.500 sampai 3.000 meter di atas permukaan laut. Lihat Budi Susanto, Ge(Mer)Lap Nasionaltas Postkolonial (Yogyakarta: Kanisius, 2008). 54

${ }^{10}$ Berdasarkan legenda orang Minangkabau, nenek moyang orang Minangkabau adalah Iskandar Zulkarnain (Iskandar Yang Agung) Maharaja Diraja yang merupakan anak dari Alexander berserta rombongannya mendarat dan tiba di Gunung Merapi yang pada waktu itu sebesar telor itik

${ }^{11}$ Luhak jika dalam bahasa Minangkabau dimaknai dengan istilah kurang, karena ketika penduduk mencari penukiman baru, penduduk ditempat asal menjadi luak 
kedua adalah Luhak Agam, Luhak Lima Puluh Koto. Berikut ini adalah nama-nama wilayah yang termasuk kedalam masing-masing Luhak antara lain:

Nagari-nagari (wilayah-wilayah) yang termasuk kedalam Luhak tanah Data adalah: (Pagaruyung, Sungai tarab, Limo Kaum, Sungayang, Saruaso, Sumanik, Padang Gantiang, Batusangka, Batipuh 10 koto, Lintau Buo, Sumpur Kuduih, Duo puluoh koto, Koto Nan Sambilan, kubang Tigobaleh, Koto Tujuah, Supayang, Alahan Panjang, Ranah Sungai Pagu.

Nagari-nagari yang termasuk ke dalam wilayah Luhak Agam adalah: Agam tuo, tujuh lurah salapan koto, Maninjau, Lawang, Matua, Ampek Koto, Anam Koto, Bonjol, Kumpulan Suliki.

Nagari-nagari yang termasuk kedalam luhak lima puluh kota adalah: Buaiyan Sungai Balantik, Sarik Jambu Ijuak, Koto Tangah, Batuhampa, Durian Gadang, Limbukan, Padang Karambie, Sicincin, Aur Kuniang, Tiakar Payobasuang, Bukik Limbuku, Batu Balang Payokumbuah, Koto nan Gadang (dari Simalanggang sampai Taram). ${ }^{12}$

Rantau adalah wilayah kultural kedua suku Minangkabau yaitu dataran rendah, dimulai dari daerah pantai timur Sumatera. Ke utara luhak Agam: Pasaman, Lubuk Sikaping dan Rao. Kemudian bagian selatan dan Tenggara luhak Tanah Data; Solok Silayo, Muaro Paneh, Alahan Panjang, Muaro Labuah, Alam Surambi Sungai Pagu, Sawah Lunto Sijunjung, sampai ke perbatasan Riau dan Jambi. Daerah ini juga disebut sebagai Ikue Rantau. $^{13}$

Pesisir, Wilayah ini berada di Sepanjang pantai barat Sumatera yaitu mulai dari Utara sampai ke Selatan: Meulaboh, Tapak Tuan, Singkil, Sibolga, Sikilang, Aie Bangih, Tiku, Pariaman, Padang, Bandar Sapuluah (terdiri dari; Air Haji, Balai Salasa, Sungai Tunu, Punggasan, Lakitan, Kambang, Ampiang Parak, Surantiah, Batang Kapeh, Painan/ Bungo Pasang) dan sampai seterusnya. ${ }^{14}$

\section{Sistem Keagamaan}

artinyamenjadi berkurang. Sehingga jika diambil dari bahasa Sangsekerta ini merupakan derivasi dari suku kata Iwa, artinya lapang.

12 Ferlan, "Konsep Nikah Sepupu Dalam Presfectif Adat Minangkabau Dan HukumIslam Studi Kasus Luhak Agam Lubuk Basung Sumatera Barat (Antara Syari'ah Dan Adat)." 38

${ }^{13}$ Ferlan. 38

${ }^{14}$ Ferlan. 38 
Sesuai dengan ungkapan dalam prinsip adat mereka yakni "Adat bersandi syarak, syarak bersandi kitabullah" Adat bersendikan hukum, hukum bersendikan kitab Allah, jelas sekali bahwa Agama masyarakat Minangkabau adalah Islam. ${ }^{15}$

Pada pertengahan abad ke-7 agama islam mulai memasuki tanah minangkabau sehingga pada saat itu perkembangan Islam di Minangkabau masih dikatakan usaha kebetulan saja, karena dengan adanya para pedagang yang beragama Islam datang ke Minangkabau. Pengaruh Islam juga masih terbatas pada wilayah-wilayah yang didatangi oleh para pedagang-pedagang Islam yaitu di sekitar wilayah kota-kota dagang di pantai Timur Sumatera. Masuknya agama Islam itu ada yang secara langsung dibawa oleh pedagang Arab dan ada juga yang dibawa oleh Pedagang India atau lainnya, artinya tidak langsung dating dari negeri Arab. ${ }^{16}$

Agama Islam ketika abad ke 17 tumbuh dan berkembang sebagai faktor penting dalam perkembangan sejarah dan kebudayaan Minangkabau pada abad-abad berikutnya. Namun, pada mulanya ada perbedaan ajaran antara adat Minangkabau dan agama Islam khususnya dalam permasalahan mengenai Hukum kekerabatan dan hukum waris telah menyebabkan timbulnya serangkaian masalah dalam hukum perdata, yang memerlukan penyesuaian mendasar dalam kaidah hukum serta kelembagaan sosial. Oleh karena masyarakat Minangkabau tidak mempunyai tatanan kelembagaan di atas tingkat nagari, maka rangkaian goncangan dan perubahan sosial tersebut hanya diselesaikan secara lokal, dan belum pernah dikonsolidasikan secara menyeluruh, terarah, terpadu, dan terencana. ${ }^{17}$

Proses Islamisasi berjalan terus secara damai melalui pengaruh yang tidak dipaksakan dan berhasil dengan baik, pengajian agama diberikan kepada orang dewasa oleh para ulama dan kitab suci Al-Qur'an mulai diajarkan termasuk kepada anak-anak dan berhasil dijadikan bahan bacaan harian putra-putri Minangkabau bila sudah berumur tujuh hingga delapan tahun ke atas. Kemudian rumah tempat mengaji adalah rumah keluarga yang disediakan untuk tempat anak-anak mengaji, guru mengaji biasanya salah

\footnotetext{
${ }^{15}$ Witrianto, "Agama Islam Minangkabau” (2010).

${ }^{16}$ Aulia Rahmat, "Reaktualisasi Nilai Islam Dalam Budaya Minangkabau Melalui Kebijakan Desentralisasi," El-Harakah 13, no. 1 (2011). 3

${ }^{17}$ Rahmat. 4
} 
seorang anggota rumah bersangkutan atau guru lain yang didatangkan untuk jadi pengajar. ${ }^{18}$

Dakwah dan dukungan kaum Padri dalam menyebarkan agama Islam menggunakan metode pendekatan Tasawuf dan Tarekat. Dakwah salafi memakai metode penyucian jiwa yaitu Tazkiyatun Nafs penyucian jiwa. Gerakan Paderi di Minangkabau menggunakan pola Tazkiyatun nufus dengan menyentuh hati masyarakatnya terlebih dahulu dalam berdakwah. ${ }^{19}$

Da'i dalam kaum Paderi ini sendiri adalah orang yang belajar agama dari Mekah. Dan di antara mereka adalah termasuk ulama nan salapan. Mereka biasa disebut oleh Masyarakat Minang dengan sebutan Tuanku, Tengku, dan Buya atau Abuya. Atau sama dengan sebutan Kyai. Syaikh dan Ustadz. $^{20}$

Materi Dakwah yang digunakan kepada masyarakat Minangkabau adalah tentang aqidah, tasawuf, dan juga pelestarian budaya jadi tidak selalu mengenai keagamaan misalnya, mengenai pidato adat, silat, belajar pantun/syair dengan berbahasa Minang. Jika materi Dakwah yang dihubungkan dengan kebudayaan minang adalah Sholawatan nya berbeda dengan pulau Jawa dan lainnya. tapi adanya (mando'a). tradisi tasyakuran mengajak orang makan kemudian mendengarkan petuah-petuah datok/ketua adat/ketua kampung. ${ }^{21}$

\section{Hukum Adat Minangkabau}

Minangkabau memiliki Hukum Adat yang tertuang dalam suatu Undang-undang, masyarakat sering menyebutnya dengan nama Undangundang nan dua Puluh, yang kemudian undang-undang ini terbagi atas 2 bagian yaitu: (undang-undang dua belas (duo baleh) dengan undang-undang nan salapan), undang-undang nan Salapan/delapan ini mengenai pengelolaan nama-nama kesalahan dan jenis kejahatan, kemudian Undangundang nan Dua Belas (Duo Baleh) yaitu mendefinisikan rasa bersalah kemudian alasan menangkap dan menghukum seseorang. Sehingga undang-

\footnotetext{
${ }^{18}$ Witrianto, "Agama Islam Minangkabau." 115

${ }^{19}$ Witrianto. 115

${ }^{20}$ Witrianto. 116

${ }^{21}$ Witrianto. 116
} 
undang duo baleh (dua belas ini) terbagi atas dua bagian masing-masing terdiri atas 6 bagian. $^{22}$

Berikut ini adalah penjelasan menganai Undang-undang nan Dua Puluh:

MR. G. D. WILLINCK menyatakan dalam bukunya Het

Rechtsleven Bij De Minangkabausche Maleiers (1909: 53)

:

oendang-oendang nan doeo poeloeah (de wet van twintig) en is verdeeld in twee groepen: $1^{\circ}$. de wet van acht (reeds boven vermeld), die de delicten groepeert, $2^{\circ}$. de wet van twaalf (oendang-oendang nan doeo balèh), de bewijsteer behandelend. Deze laatste wordt dan weer onderscheiden in ,de wet der eerste zes" (over de bewijzen) en ,de wet der laatste zes" (over aanwijzingen). De eerste zijn ,,zoo helder als de dag", de tweede „,zoo, klaar als bij maneschijn”, samen heeten deze bewijzen en aanwijzingen ook wel tando bêti. Men schijnt hieronder dan een on- derdeel van de adat nan doeo balèh te moeten verstaan. Immers tegenover die tando bêti, staan de tando tjëtno en tando djahè', middelen om den dader op te sporen, ook deel uitmakende van de ,wet van twaalf". Er zouden wel 25 van elk dier tando zijn.

[Undang-undang nan dua puluh (Undang-Undang Dua Belas) terbagi ke dalam dua kelompok, 1. Hukum delapan, yang terkelompokan dalam delik2. Hukum dua belas (oendang-oendang nan duo baleh, hukum ini dibedakan dalam enam hukum pertama (terkait bukti-bukti) dan hukum enam terakhir (terkait petunjuk-petunjuk). Yang pertama, "layaknya cahaya di kala siang", sedangkan yang kedua, "layaknya sinar rembulan yang muncul menjelang malam". Bukti-bukti dan petunjuk ini memiliki nama yang begitu mirip, tando beti (tanda bukti). Orang-orang nampaknya harus memahaminya sebagai satu bagian dari adat nan doeo baleh. Di sisi lain berlainan dengan tando beti, ada tando tjemo dan tando djahe. Suatu cara

${ }^{22}$ A. Irzal Rias, "Customary Crime Settlement Based on the Adat Law of Minangkabau: A Criminological Study," Academic Research International 5, no. 2 (2014). 538 
untuk mengusut pelaku kejahatan, juga merupakan bagian dari hukum dua belas. Ada 25 pasal dari setiap tanda]. ${ }^{23}$

Undang-undang nan dua puluh $h^{24}$ ialah, undang-undang Minangkabau mengenai tentang hukum adat $\operatorname{delik}^{25}$ di Minangkabau, Yakni mengenai aturan tentang hukum pidana adat. Kemudian, masyarakat mengetahui undang undang lainnya yang mana masyarakat memberikan nama yang istimewa seperti, undang-undang negeri dan luhak, undang-undang nan dalam negeri, undang-undang nan sembilan pucuk dan lain lain, tetapi semua ini tidak melingkupi gambaran utuh dari undang-undang ini dan lebih kepada sebuah traktat moral, atau compedia svoir-vivre dari sebuah buku hukum. Undang-undang nan dua puluh ini terbagi atas dua bagian, yaitu Undangundang nan Salapan dan Undang-undang nan Duobaleh, UU Nan Salapan menentukan perbuatan kejahatan, dan UU Nan Duobaleh menjelaskan tanda bukti yang melanggar UU Nan Salapan.

Tabel 1 Undang-undang nan Salapan

\begin{tabular}{|l|l|l|}
\hline No & $\begin{array}{c}\text { Delik } \\
\text { (tindakan) }\end{array}$ & \multicolumn{1}{|c|}{ Penjelasan } \\
\hline 1. & $\begin{array}{l}\text { Tikam } \\
\text { bunuh }\end{array}$ & $\begin{array}{l}\text { Tikam: perbuatan yang melukai orang } \\
\text { Bunuh: perbuatan menghilangkan nyawa orang dengan } \\
\text { menggunakan kekerasan }\end{array}$ \\
\hline 2. & $\begin{array}{l}\text { Upeh } \\
\text { racun }\end{array}$ & $\begin{array}{l}\text { Perbuatan yang menyebabkan seseorang menderita sakit } \\
\text { setelah menelan makanan atau minuman yang telah diberi } \\
\text { ramuan yang berbisa }\end{array}$ \\
\hline 3. & $\begin{array}{l}\text { Samun } \\
\text { saka }\end{array}$ & $\begin{array}{l}\text { Samun: perbuatan merampok milik orang dengan cara } \\
\text { melakukan pembunuhan. }\end{array}$ \\
\hline
\end{tabular}

23 M. Joustra, Minangkabau Overzicht Van Land, Geschiedenis En Volk (Gravenhage: Martinus Nijhoff, 1923). 122

${ }^{24}$ Tentang UU Nan Duo Puluah ini lebih lanjut lihat Datoek Toeah, Tambo Alam Minangkabau (Bukit Tinggi: Pustaka Indonesia, n.d.).

${ }^{25}$ Delik adalah pasal mengenai hukum, pidana, perdata. Delik adalah pengertian umum tentang semua perbatan yang melanggar hukum ataupun undang-undang dengan tidak membedakan apakah pelanggaran itu di hukum privat atau hukum public, termasuk hukum pidana. Lihat Ahmad Ali, Menguak Tabir Hukum (Jakarta: Kencana, 2015). 325 


\begin{tabular}{|l|l|l|}
\hline & & $\begin{array}{l}\text { Saka: perbuatan merampok milik orang dengan kekerasan } \\
\text { dianiaya. }\end{array}$ \\
\hline 4. & Sia Baka & $\begin{array}{l}\text { Sia: Perbuatan membuat Api yang mengakibatkan milik } \\
\text { orang lain sampai terbakar } \\
\text { Baka: } \text { Perbuatan membakar barang orang yang sampai } \\
\text { hangus dan habis tidak tersisa. }\end{array}$ \\
\hline 5. & $\begin{array}{l}\text { Maliang } \\
\text { Curi }\end{array}$ & $\begin{array}{l}\text { Maliang perbuatan mengambil milik orang dengan } \\
\text { melakukan perusakan atas tempat menyimpannya } \\
\text { Curi: curi ialah perbuatan mengambil milik orang lain }\end{array}$ \\
\hline 6. & Dago Dagi & $\begin{array}{l}\text { Dago: perbuatan pengacauan dengan desas-desus } \\
\text { sehingga terjadi kehebohan } \\
\text { Dagi: perbuatan menyebarkan fitnah sehingga merugikan } \\
\text { yang bersangkutan }\end{array}$ \\
\hline 7. & $\begin{array}{l}\text { Kicuah } \\
\text { kicang }\end{array}$ & $\begin{array}{l}\text { Kicuah: ialah perbuatan penipuan yang mengakibatkan } \\
\text { kerugian orang lain } \\
\text { Kicang: perbuatan pemalsuan yang dapat merugikan } \\
\text { orang lain }\end{array}$ \\
\hline 8. & $\begin{array}{l}\text { Sumbang } \\
\text { Salah }\end{array}$ & $\begin{array}{l}\text { Sumbang: perbuatan yang melakukan sesuatu tidak pada } \\
\text { tempatnya atau bersalahan menurut pandangan mata } \\
\text { orang banyak } \\
\text { Salah: ialah perbuatan melakukan zina. }\end{array}$ \\
\hline
\end{tabular}

Sumber:Di olah dari A. Irzal Rias, 2014, "Customary Crime Settlement Based on the Adat Law of Minangkabau: A Criminological Study", Academic Research International, Vol. 5(2). Hlm. 438.

Undang-undang nan dua baleh, (dua belas) ini adalah bagian dari undang-undang dua puluh yang mencantumkan dua belas pasal, yang dapat menjadi alasan untuk menangkap dan menghukum seseorang. Kemudian

${ }^{26}$ Rias, "Customary Crime Settlement Based on the Adat Law of Minangkabau: A Criminological Study." 49 
undang-undang ini terbagi atas dua bagian (masing-masing mempunyai enam pasal). Berikut ini adalah uraian pasalnya:

Tabel 2 Undang-undang Nan Duo Baleh (dua belas)

\begin{tabular}{|c|c|c|}
\hline No & $\begin{array}{c}\text { UU Nan Duo } \\
\text { Baleh }\end{array}$ & Definisi \\
\hline 1. & Tatu mbuak & $\begin{array}{l}\text { Terdakwa harus mengakui bahwa dialah orangnya } \\
\text { melakukan aksinya. }\end{array}$ \\
\hline 2. & $\begin{array}{l}\text { Tatando } \\
\text { Tabukti. }\end{array}$ & $\begin{array}{l}\text { Tatando: berarti barang-barang pribadi dari terdakwa } \\
\text { ditemukan di tempat kejadian } \\
\text { Tabukti: bukti yang melekat pada tubuh atau pakaian }\end{array}$ \\
\hline 3. & Taikek takabek & $\begin{array}{l}\text { Taikek: berarti orang yang melakukan kejahatan } \\
\text { tertangkap } \\
\text { Takabek: terdakwa melakukan kejahatan ditangkap } \\
\text { dan dia tidak bisa melarikan diri dari tempat itu. }\end{array}$ \\
\hline 4. & $\begin{array}{l}\text { Tercencang } \\
\text { Tarageh }\end{array}$ & $\begin{array}{l}\text { Tercencang: jejak yang ditemukan sebagai hasil dari } \\
\text { tindakan terdakwa di tempat kejadian. Tarageh: telah } \\
\text { ditemukan dalam tubuh terdakwa } \\
\text { tanda yang disebabkan oleh objek yang ada di tempat } \\
\text { kejadian. }\end{array}$ \\
\hline 5. & $\begin{array}{l}\text { Tahambek } \\
\text { Tapukua }\end{array}$ & $\begin{array}{l}\text { Tahambek: terdakwa tidak bisa lepas dari orang } \\
\text { Mengelilinginya Tapukau: terdakwa ditangkap } \\
\text { setelah dia dipukuli orang yang mengejarnya }\end{array}$ \\
\hline 6. & Talalah Takaja & $\begin{array}{l}\text { Talala: terdakwa ditemukan di tempat } \\
\text { persembunyian setelah melacak. Takaja: yang } \\
\text { menjadi tersangka bisa ditangkap dalam pengejaran. }\end{array}$ \\
\hline 7. & $\begin{array}{l}\text { Basuruik bak } \\
\text { sipasan bajajak } \\
\text { bak bakiak }\end{array}$ & $\begin{array}{l}\text { Jejak ditemukan di bumi menuju } \\
\text { tertuduh. }\end{array}$ \\
\hline
\end{tabular}




\begin{tabular}{|l|l|l|}
\hline 8. & $\begin{array}{l}\text { Anggang lalu } \\
\text { atah jatuah }\end{array}$ & $\begin{array}{l}\text { Seseorang ditemukan di tempat kejadian bersamaan } \\
\text { dengan tindakan itu dilakukan }\end{array}$ \\
\hline 9. & $\begin{array}{l}\text { Kecondongan } \\
\text { mato urang } \\
\text { banyak }\end{array}$ & Pada saat kejadian, banyak mata melihatnya \\
\hline 10. & $\begin{array}{l}\text { Bajura bamurah } \\
\text { murah }\end{array}$ & $\begin{array}{l}\text { Seseorang menjual barang atau barang dengan harga } \\
\text { sangat rendah, jadi insiden ini menimbulkan } \\
\text { kecurigaan bahwa barang-barang itu bukan miliknya. }\end{array}$ \\
\hline 11. & $\begin{array}{l}\text { Bajalan } \\
\text { bagageh gageh }\end{array}$ & $\begin{array}{l}\text { Terdakwa berjalan dengan cepat; dari wajahnya } \\
\text { menunjukkan dia takut }\end{array}$ \\
\hline 12. & $\begin{array}{l}\text { Dibaok pikek, } \\
\text { dibaok langau }\end{array}$ & $\begin{array}{l}\text { seseorang hilir-mudik pada suatu tempat tanpa } \\
\text { diketahui maksudnya dengan jelas sehingga } \\
\text { menimbulkan kecurigaan }\end{array}$ \\
\hline
\end{tabular}

Sumber: di olah dari A. Irzal Rias, 2014, "Customary Crime Settlement Based on the Adat Law of Minangkabau: A Criminological Study", Academic Research International, Vol. 5(2). Hlm. 438.

\section{Undang-undang Sumatera Barat Tahun 1837-1862}

\section{Penulisan Undang-undang Sumatera Barat pada Tahun 1837-1862}

Setelah Belanda menguasai sistem pemerintahan ditanah Minangkabau, Belanda merasa pintu terbuka ketika terjadi konflik antar golongan masyarakat yakni golongan para ulama dengan tokoh hukum adat (golongan putih dan hitam), yang kemudian ini dikenal dengan sebutan Perang Padri. Belanda memanfaatkan situasi ini dengan cara membantu peperangan tehadap golongan hukum adat yang nantinya padahal golongan hukum adat ini hanya dikelabuhi kemudian dikhianati. Perang Padri ini terjadi sekitar pada tahun 1818-1838, setalah beberapa kali terjadi serang menyerang antara kedua belah pihak dan pada akhirnya belanda ikut campur sehingga pada akhirnya perang ini dimenangkan oleh pihak Belanda dan semakin berkuasa lah Belanda di tanah Minangkabau.

\section{${ }^{27}$ Rias. 49}


Belanda semakin berkuasa setelah berhasil menaklukan perang Padri dengan melanjutkan berbagai kegiatan di tanah jajahan salah satunya yaitu mengubah tradisi masyarakat Minangkabau yang terkenal dengan tradisi lisan kemudian menjadi tradisi tulisan. salah satu bentuknya yaitu Undangundang nan duo baleh (nan dua puluh) dan undang-undang Sumatera Barat.

\section{Isi Drie Oendang-oendang's West Kust Sumatra's / isi Tiga Undang- undang dari Pantai Barat Sumatera}

Undang-undang Sumatera Barat yang dituliskan pada tahun 18371862 atas perintah Residen Heinmers Undang-undang ini ditulis melalui surat aturan adat dalam nagari yang isinya menguraikan beberapa aturan. Secara garis besarnya Undang-undang Sumatera Barat ini berisikan 3 poin yang kemudian dibagi lagi menjadi beberapa point, 3 poin ini secara garis besar berisi mengenai: Undang-undang adat dalam nagari beserta cara penyelesaian suatu permasalahan dalam nagari tersebut, Undang-undang adat perkara pembunuhan kemudian Undang-undang adat bersanding Syara. ${ }^{28}$

\section{Undang-undang adat dalam nagari:}

Undang-undang ini merupakan bagian dari undang-undang Sumatera barat. Undang-undang ini memuat 8 pasal bagian pertama hingga keempat isinya mengenai kepemimpinan seorang imam, penghulu dalam suatu laras kota, atau suatu wilayah di tanah Minangkabau kemudian ke lima hingga delapan membahas mengenai penyelesaian suatu permasalahan dalam suatu wilayah yang bersangkutan. Berikut dibawah ini adalah poin-poin mengenai UU tersebut:

Berikut dibawah ini adalah isi poin pertama pada naskah undangundang adat dalam nagari yakni membahas mengenai seorang imam dan kepala dalam suatu desa/kampung.

"Pertama maka dalam tiap-tiap laras ada djoega sa orang imam dan doewa tiga orang jang djadi kepala dalam tiap-tiap satoe laras"

Isi naskah tersebut menjelaskan, ketika sebelum para penjajah Belanda masuk ke tanah Minangkabau maka dalam setiap suatu perkumpulan desa ada seorang Imam dan dua atau tiga orang yang menjadi ketua dalam setiap laras (perkumpulan desa) tersebut.

28 “Manuskrip Drie Oendang-Oendang’s Sumatra's Kesthust," n.d. 
Undang-undang pada poin yang kedua ini membahas mengenai suatu wilayah yang tidak memiliki raja. Berikut di bawah ini poin kedua yang sebelumnya ditulis pada naskah undang-undang Sumatera Barat:

"Dalam Negari jang tiada radja maka imam itoelah jang akan ganti radja, adapoen nan djadi imam itoe orang jang alim mangatahoei perdjalanan sjara dan mangatahoei hoekoem adat nan bersandi sjara lagi patoet dan berbangsa dalam indoek negrinja nan satoe laras itoe tetapi tiada di dirikan dengan moefakat malainkan soedah lahir sadja dalam negri”.

Poin Kedua ini, menjelaskan jika di dalam suatu nagari/kota tidak ada seorang raja maka otomatis imam yang harus menggantikan tugas seorang raja. Adapun syarat seorang imam itu harus seseorang yang alim serta mengetahui perjalanan Syara' dan mengetahui hukum adat bersama syara', serta seseorang yang berbangsa dalam induk suatu nagarinya/kota.

Berdasarkan isi pada naskah Undang-undang adat dalam nagari pada poin yang ketiga memaparkan mengenai pengulu Andiko sebagai kepala dalam suatu desa.

"Adapoen jang kepala dalam tiap-tiap satoe laras ijalah siapa pangoloe andiko jang patoet lagi tjeidek dan pandei dalam indoek negerinja yang tiap-tiap satoe laras".

Kepala dalam tiap-tiap wilayah dalam suatu perkumpulan desa tersebut yaitu pangoloe andiko (datuak kampung pemimpin dari warga kampungnya) yang menyelesaikan perkara atau suatu permasalahan yang dihadapi warga kampungnya. Jika suatu perkara masih belum ditangani oleh orang yang bersangkutan maka perkara dibawa kepada tunggani (pangkat dibawah penghulu andiko) kemudian jika masih tidak dapat diselesaikan maka perkara baru di bawa kepada penghulu andiko ${ }^{29}$

Pada poin keempat membahas mengenai tiga jenis tokoh yang mempunyai peranan penting pada suatu kota.

"Orang dalam negeri bernama tiga djinis pertama pangoeloe andiko, kadoewa imam chatib, katiga pilih hoelubalang artinja toengkat pangoeloe

${ }^{29}$ Munir Taher, “Silungkang Dalam Sejarah,” 2007, munirtaher.wordpress.com. 
jang di namai orang bersoekoe serta tjerdik pandai dalam negeri, maka namai oendang-oendangnja pangoeloe nan sa andiko malim nan sakitab hoelobalang nan samaloe dan padoeri nan sacara".

Menurut poin keempat Ada tiga jenis tokoh penting dalam suatu nagari/kota yaitu. Tokoh penting tersebut adalah yang pertama, penghulu Andiko. (adalah datuak kampung atau seorang pemimpin dan tugasnya adalah menyelesaikan suatu perkara yang dihadapi warga kampungnya (yudikatif, hakim). Kedua, Imam Khatib (Imam ialah seseorang yang memimpin keagamaan (Islam) dan menyelenggarakan kegiatan nya di masjid, sedangkan khatib adalah seseorang yang selalu berkhotbah diatas mimbar masjid.(legislatif)) Ketiga, hulubalang (seorang kepala dalam sebuah kota atau suatu wilayah (eksekutif)). Ketiga tokoh tersebut dipandang memiliki status sosial yang tinggi bagi masyarakat karena ketiga tokoh tersebut di nilai seseorang yang bersuku dan yang cerdik serta pandai dalam kotanya.

Berdasarkan uraian pada poin keempat ini, bhawa undang-undang adat dalam nagari ini memang dijalankan salah satunya yaitu: Pemerintahan Hindia Belanda mengesahkan Tungku Tigo Sajarangan, Ninik Mamak, Alim Ulama dan Cadiak Pandai, sebagai unsur-unsur (partai) yang mewakili rakyat dalam pemerintahan Nagari dan kerapatan Nagari (legislative Nagari), artinya dalam struktur diatas terlihat bahwa Alim Ulama (AU), Cadiak Pandai (CP), Penghulu Kaum atau Kepala Kaum (KK). Penghulu yang diangkat oleh Pemerintahan Hindia Belanda masuk ke dalam lembaga dan kerapatan ninik mamak yang sekaligus mewakili kerapatan Nagari. sementara kerapatan Nagari merupakan subordinat dari kepala Nagari, Secara structural Pemerintahan Nagari dibuat oleh Hindia Belanda seperti ini sehingga membuat masyarakat yang ada dalam nagari terkooptasi kekuasaan kepala Nagari yang diangkat oleh pemerintahan Hindia Belanda. ${ }^{30}$

Poin kelima ini membahas tentang penyelesaian suatu permasalahan pada suatu wilayah yang bersangkutan berikut dibawah ini adalah isi dalam naskah:

${ }^{30}$ Taher. 
"Kaloe tomboeh apa-apa hal perkara dalam satoe negri maka perkara itoe ditimbang dengan sapandjang adat oleh rapat pangoeloe orang nan 3 djinies dalam satoe-satoe negrinja masing-masing".

Jika bertambahnya perkara dalam sebuah nagari/kota maka perkara tersebut ditimbang dengan undang-undang Sumatera barat. Penghulu akan merapatkan perkara tersebut bersama para tokoh yang tiga jenis (seperti yang disebutkan pada point keempat diatas) dalam kota masing-masing

Poin keenam pada naskah undang-undang adat dalam nagari menjelaskan mengenai penyelesaian suatu permasalahan antara satu negeri dengan negeri lainnya. Berikut adalah isinya:

"Kaloe tomboeh apa-apa hal perkara satoe negri dengan satoe negri dalam nan satoe latar maka perkara itoe ditimbang dengan sapandjang adat oleh rapat pangoeloe orang nan tiga djinis juga dalam kedoewa pihak negrinja"

Berdasarkan poin keenam diatas jika dalam suatu kota terjadi permasalahan namun masih dalam satu wilayah maka perkara tersebut ditimbang atau dapat diselesaikan dengan aturan undang-undang Sumatera Barat. Penghulu akan merapatkan perkara tersebut bersama para tokoh yang tiga jenis (seperti yang disebutkan pada point keempat diatas) dalam kota masing-masing

Pada poin ketujuh ini yaitu penyelesaian suatu permasalahan yang disebutkan pada poin kelima dan keenam jika sebelumnya tidak dapat juga selesai. Berikut di bawah ini adalah yang tertulis pada naskah:

"Kaloe tiada dapat samapakat rapat segala pangoeloe orang nan tiga djinis jang tersaboet dalam perkara jang kalima dan dalam perkara jang kaanam diatas ini maka perkara itoeh bawa kapada rapat pangoeloe orang nan tiga djinis jang djadi kapala dalam nan satoe laras itoe, dan kiranja djikalaoe tidak dapat djoega samoefakat segala marika itoe maka di bawa perkara itoe kapada siapa jang djadi imam dalam nan satoe laras itoe"

Jika dalam rapat penghulu tiga jenis perkara yang telah disebutkan pada poin yang kelima dan keenam diatas masih belum sepakat maka perkara tersebut kemudian dibawa ketika rapat penghulu yang tiga jenis 
bersama tokoh yang menjadi kepala pada suatu acara dalam suatu laras itu, tetapi jika kemudian masih belum bisa mufakat maka perkara tersebut dibawa kembali dan dapat diselesaiikan bersama imam dalam suatu laras (perkumpulan desa) tersebut.

Berikut di bawah ini Poin kedelapan berdasarkan pada naskah undang-undang adat dalam nagari yaitu menyelesaikan suatu permasalahan yang kembali tumbuh di suatu desa:

"Kaloe toemboeh apa-apa hal perkara dalam satoe laras, maka berkompoel segala pangoloe orang nan tiga djinis dalam tiap-tiap negri nan satoe laras itoe pada tampat perhimpoenan segala marika itoe akan manimbah bagaimana nan Sapandjang adat, dan bagimana jang daapat dalam timbangan segala marika itoe baharoelah ditetabkan dan kiramya kaloe tidak dapat semoefakat maka dibawa perkara itoe kapada siapa jang djadi imam saperti jang telah tersaboet di atau ini djoega, maka imam itoe manimbang sapandjang adat nan bersandi sjara, dan bagimana jang dapat dalam timbangan imam itoe tiada boleh di perbinara lagi malainkan tetab salama-lamanja”.

Jika tumbuh hal-hal perkara dalam suatu Laras (perkumpulan desa) maka berkumpulah semua penghulu yang tiga jenis pada setiap kota yang masih dalam suatu perkumpulan desa, di suatu tempat perhimpunan kemudian mereka akan menimbang Sepanjang adat, dan bagaimana hasil yang didapatkan dalam timbangan tersebut sehingga ditetapkanlah hasilnya tetapi jika tidak dapat mufakat lagi maka perkara tersebut dibawa kembali kepada siapa yang menjadi imam, maka imam menimbang berdasarkan Undang-undang adat bersandi syara maka hasil yang di peroleh dari timbangan Undang-undang adat bersandi syara ditetapkan untuk selamalamanya dan tidak bisa diubah kembali. ${ }^{31}$

Dengan kehadiran Undang-undang ini, Pemerintahan Hinida Belanda masih mempercayakan putusan perkara pada masyarakat dan Pejabat yang dipilih oleh masyarakat. Karena Pemerintah Hindia Belanda hanya akan meminta pertanggung jawaban para pejabat desa tersebut. Sehingga dapat kita amati bahwa secara terang-terangan belanda memberikan kepercayaan kepada masyarakat Minangkabau untuk memberikan kewenangan dalam hal

31 "Manuskrip Drie Oendang-Oendang's Sumatra's Kesthust." 
pemerintahan dalam nagari. Meskipun dibalik itu semua Belanda hanya ingin menguasai Minangkabau sekaligus sebagai jembatan mereka untuk memperlancar strateginya di tanah jajahan.

\section{Undang-undang Adat Perkara Pembunuhan}

Undang-undang perkara pembunuhan merupakan bagian yang termasuk kedalam undang-undang Sumatera Barat. Undang-undang perkara pembunuhan ini memuat tiga poin mengenai definisi perbuatan terdakwa serta hukuman yang dijatuhkan yang harus dipenuhi. UU ini dilengkapi dengan 5 klasifikasi bagi para doensanak (Saudara yang segaris keturunan dengan nenek dari ibu/ayah) yang akan membantu terdakwa memenuhi hukuman yang telah ditentukan. Untuk lebih jelasnya berikut di bawah ini adalah poin-poin nya:

Undang-undang perkara pembunuhan poin pertama ini membahas tentang pembunuhan yang disengajai berikut di bawah ini adalah isi pada naskah:

"Boenoeh amat artinya die sangadja nan bersamaan hoekoemnja kitstas atau diyat arta nan mamboenoeh sandierie"

Perlakuan membunuh dengan sengaja dan telah direncanakan maka hukumannya adalah dengan ancaman kishas atau membayar diyat dengan harta milik terdakwa

Undang-undang perkara pembunuhan poin kedua membahas mengenai pembunuhan yang tidak disengaja. Di bawah ini adalah yang tertera pada naskah undang-undang adat perkara pembunuhan:

"Boenoeh chatak artinya tiedak die sangadja oepama manembak binatang atau boeroeng karnanj saorang, orang terlaloe hatija"

Perlakuan membunuh dengan tidak disengaja karena salah sasaran seperti awalnya akan menembak binatang atau se-ekor burung tetapi malah salah sasaran karenanya dia sendiri.

Poin ketiga memaparkan mengenai seseorang yang membunuh dengan menggunakan alat tajam berikut dibawah ini adalah isi pada naskah: 
"Soeboe amad artinya menikam orang dengan djaroem atau lain sindjata jang tiedak patoeb mamboenoeh maka matie orang itoe kadoeuwa roepanya itue hoekumnja diyat hoetang, atas akalah artinja sagala soedaranja nan lakie mambayar"

Soeboe amad adalah Perlakuan menikam seseorang dengan cara menggunakan alat tajam seperti jarum, senjata dan alat lainnya yang tidak layak digunakan untuk membunuh. Maka hukuman bagi pelaku tersebut adalah harus membayar diyat atau menjadi hutang dan segala saudara lakilaki bisa membantu untuk membayar terdakwa.

Ada pengecualian bagi terdakwa untuk dibantu oleh sanak saudara nya, pengecualiaannya yaitu: Jika saudara kandung laki-laki tidak dapat membayar maka saudara bapak laki-laki saja yang membayar diyat, Jika saudara laki-laki bapak masih tidak dapat membayar maka anak saudara bapak saja yang membayar diyat, Saudara bapak yang satu ibu dan satu bapak saja yang membayar diyat, jika tidak bisa maka Anak saudara bapak yang satu bapak saja yang membayar ${ }^{32}$

Tabel 3 Klasifikasi doensanak yang membantu terdakwa

\begin{tabular}{|c|c|c|}
\hline $\mathrm{NO}$ & Kasifikasi & Definisi \\
\hline 1. & $\begin{array}{l}\text { Pertama Nan pokok } \\
\text { mambonoeh } \quad \text { mantjarie } \\
\text { oewang padoewa diyat }\end{array}$ & $\begin{array}{l}\text { Terdakwa dalam perkara pembunuhan } \\
\text { maka harus mencari uang untuk } \\
\text { membayar diyat }\end{array}$ \\
\hline 2. & $\begin{array}{l}\text { Kadoewa doensanak iboe } \\
\text { doensanak mentjarie } \\
\text { oeuang } 1 / 4 \text { saparampat diyat } \\
\text { barsama-sama mana-mana } \\
\text { yang labih dakat maka } \\
\text { labih gadang mambarie } \\
\text { oeuang }\end{array}$ & $\begin{array}{l}\text { Saudara satu garis keturunan dengan } \\
\text { nenek dari ibu/ayah membayar diyat } 1 / 4 \text {, } \\
\text { dengan yang mana yang lebih dekat } \\
\text { maka itu yang lebih besar memberi } \\
\text { uang. }\end{array}$ \\
\hline 3. & $\begin{array}{l}\text { Katiga doensanak poeyang } \\
\text { atau labih djaoeh } \\
\text { mantcarie oewang } 1 / 8\end{array}$ & $\begin{array}{l}\text { Saudara nenek moyang yang lebih jauh } \\
\text { mencari uang } 1 / 8 \text { seperdelapan bangun }\end{array}$ \\
\hline
\end{tabular}

${ }^{32}$ Manuskrip Drie Oendang-oendang's Sumatra's Kesthust 


\begin{tabular}{|c|c|c|}
\hline & $\begin{array}{l}\text { sapersalapan bangoen } \\
\text { barsama-sama barapa diya } \\
\text { ada }\end{array}$ & dan berapapun adanya. \\
\hline 4. & $\begin{array}{l}\text { Kaampat doensanak } \\
\text { pasoekoewan bersama nan } \\
\text { sagenggam padang, } \\
\text { mantjarie oewang } \\
\text { saperanambalas bersama- } \\
\text { sama barapa diya ada }\end{array}$ & $\begin{array}{l}\text { Saudara satu garis keturunan dengan } \\
\text { nenek dari ibu/ayah dan satu suku dan } \\
\text { segenggam tanah, mencari uang yakni } \\
\text { 1/16 bersama-sama berapapun dia } \\
\text { adanya. }\end{array}$ \\
\hline 5. & $\begin{array}{l}\text { Kalima, orang nan satoe } \\
\text { parboewatan ada joega } \\
\text { lain soekoe mantjarie } \\
\text { oewang saperanam balas } \\
\text { banggoen, barsama-sama } \\
\text { barapa-barapa diya ada. }\end{array}$ & $\begin{array}{l}\text { Orang yang satu perbuatan ada juga suku } \\
\text { lain yang mencari uang } 1 / 16 \text { bangun } \\
\text { bersama-sama berapa dia adanya. }\end{array}$ \\
\hline
\end{tabular}

Sumber: diolah dari Manuskrip Drie Oendang-oendang's Sumatra's Kesthust

Untuk lebih lanjutnya dibawah ini penjelasan mengenai hitungan para doensanak yang akan membantu terdakwa mengenai perkara perlakuan suatu pembunuhan:

\begin{tabular}{|c|c|}
\hline 1 Bangoen & ${ }^{34} f \underline{800-“ " ~}$ \\
\hline 1/2 Bangoen & $f 400-^{66}$ \\
\hline 1/4 Bangoen & $200-“ 6$ \\
\hline $1 / 8$ Bangoen & $100-^{\text {“6 }}$ \\
\hline 1/16 Bangoen & $50-{ }^{66}$ \\
\hline 1/16 Bangoen & $50-{ }^{66}$ \\
\hline 1 Bangoen djumlahnja & $f 800-“$ \\
\hline \multicolumn{2}{|c|}{$\begin{array}{l}{ }^{33} \text { Manuskrip Drie Oendang-oendang's Sumatra's Kesthust } \\
{ }^{34} \text { Simbol } f \text { adalah untuk penyebutan mata uang Belanda yaitu Gulden sekitar tahun } \\
\text { nata uang ini digunakan di Hindia Belanda atau di nusantara ini. Desranov } \\
\text { rsi Nilai Mata Uang Zaman Penjajahan Belanda dengan Rupiah Republik Indonesia } \\
\text { "” Desranov.Blogspot.com. } 03 \text { Mei } 2015 \text { pukul 11:37. }\end{array}$} \\
\hline
\end{tabular}


Jika terdakwa adalah berasal dari keluarga orang kaya maka terdakwa harus membayar sebesar 6 (enam) roepia dengan berjanji selama tiga tahun dan mencicilnya dengan 2 roepia setiap satu tahun sekali dalam jangka waktu 3 ta hun. Kemudian terdakwa mencari orang pembayar atau yang membantu terdakwa dalam memenuhi hukuman akibat perlakuan pembunuhan dengan Sepanjang aturan adat yang telah diadatkan dalam suatu kota, dalam hal mematuhi syarat hukuman bagi terdakwa ada juga bentuk keringanan terhadap terdakwa yang memiliki kriteria seperti ini: terdakwa berasal dari keluarga miskin, terdakwa masih dibawah umur/anak-anak, terdakwa berjenis kelamin perempuan, kemudian terdakwa adalah orang yang tidak berakal atau mengalami gangguan jiwa. maka terdakwa tidak diwajibkan untuk membayar meski terdakwa adalah orang yang kaya sekalipun. ${ }^{35}$

\section{Undang-undang adat bersanding syara'}

Undang-undang ini memuat 8 poin yang didalam berisi mengenai hal-hal seperti: nikah, Zakat, Fitrah, Talak, pelaku halal dan haram. Maka dari itu tabel dibawah ini akan memaparkan mengenai undang-undang tersebut:

Berdasarkan isi pada naskah undang-undang adat bersanding syara', poin pertama pada undang-undang ini membahas tentang zakat, fitrah nikah dll. Berikut dibawah ini adalah isi pada naskah:

"Daripada hal zakat dan fitrah, nikah dan pelaku halal dan haram segala perkara malim dalam selaras IV kota menimbang”

Mengenai zakat, fitrah, nikah dan pelaku halal serta haram bahkan segala perkara yang terjadi pada suatu nagari/kota maka secara keseluruhannya akan di timbang kemudian diselesaikan di Laras IV Kota sesuai dengna Undang-undang Sumatera Barat.

Poin kedua pada naskah undang-undang adat bersanding syara' di bawah ini adalah berisi tentang zakat fitrah:

“Adapun perkara zakat dan fitrah tiada boleh diberikan kepada fakir miskin yang lain-lain negeri kita mempunyai hak itu Sepanjang yang tersebut dalam

\footnotetext{
${ }^{35}$ Manuskrip Drie Oendang-oendang's Sumatra's Kesthust
} 
kitab ialah segala fakir miskin yang ada dalam satu-satu nagari nya masingmasing"

Mengenai perkara zakat dan fitrah dalam sistem pembagian nya tidak boleh diberikan kepada wilayah lain, sebab zakat dan fitrah ini hanya dibagiakan diwilayah masing-masing ketika pembayaran zakat berlangsung.

Pada poin ketiga ini membahas mengenai hal talak dan nikah. Berikut ini adalah isi naskahnya:

"Daripada nikah dan talak alim dalam nagarinya seorang-sorang nan menikahkan dengan idzin wali perempuan yang akan nikah itu. Dan tiada boleh perempuan itu lain nikah ketempat lain-lain. Melainkan nan boleh dianya lari kepada saja ka kota gadang, dalam itu kalau dianya ada wali saja suruh nikahkan oleh walinya dan kalo enggan walinya ialah saja atau wakil saja nan menikahkan".

Berdasarkan pada isi naskah di atas mengenai hal perkara nikah dan talak maka otomatis seorang alim ulama dalam kotanya masing-masing yang menikahkan, dan tentunya atas izin wali dari pihak perempuan yang akan menikah. Kemudian perempuan tersebut tidak boleh menikah di tempat lain atau di kota lain, terkecuali yang diperbolehkan pergi ke kota gadang. jika perempuan tersebut hanya ada walinya saja maka dinikahkan oleh walinya tetapi jika walinya enggan untuk menikahkan maka wakil saja yang menikahkannya.

Pada poin keempat undang-undang ini membahas tentang mendrabih dan manzabih berikut adalah isi naskah pada poin keempat:

"Daripada manzabih ialah imam khatib dalam satu-satu negerinya masingmasing nan mandrabih"

Kemudian yang manzabih ialah imam khatib yang satu-satunya dalam sutu negeri masing-masing yang mandrabih.

Sesuai pada naskah undang-undang adat bersanding syara poin kelima ini membahas mengenai apabila pada poin pertama hingga keempat terjadi perselisihan maka diselesaikan pada bagian kelima ini. Berikut adalah isi naskah: 
"Daripada hal zakat dan fitrah nikah dan talak halal dan haram segala perkara malim yang tersebut diatas ini, kalo tumbuh selisih dalam tiap-tiap negeri djoko tiada habiso alimnya satu satu negeri maka bawahannya perkara itu kepada saja kakota gadang”

Dari semua perkara mengenai zakat fitrah, nikah, halal, dan haram sehingga jika dari perkara tersebut terjadi suatu perselisihan kemudian tidak dapat diselesaikan maka perkara tersebut harus dibawa ke kota gadang (sebuah wilayah yang masih satu tingkat dengan Desa di Sumatera Barat).

Bagian keenam membahas mengenai penyelesaian suatu perkara dalam Laras IV Kota. Berikut dibawah ini adalah isi naskah:

"Kalo apa-apa hal perkara dalam laras IV kota yang sampai kepada tuanku laras sama terduduki juga kami hakim, bertiga kiranya jikalau ringan perkara itu maka dihabisi saja oleh siapa yang terhadap ketika itu, kemudian diberi cadar juga bagaimana kehadirannya perkara itu kepada salah seorang kami hakim yang tiada mahakim dan kiranya jikalau berat perkara itu, maka diperjanjikan kata sampai sama terhadap kami hakim nan bertiga"

Mengenai berbagai hal perkara di laras IV Kota yang sampai kepada tuanku laras dan sampai kepada hakim, kemudian jika perkara itu ringan maka selesaikan saja oleh siapa yang menghadap ketika itu, kemudian diberikan penjelasan bagaimana terjadinya perkara itu kepada salah seorang hakim, tetapi jika sekiranya perkara tersebut berat, maka diperjanjikan kata sampai sama terhadap hakim yang bertiga.

Pada bagian ketujuh ini membahas mengenai hal keuntungan dan kerugian dalam laras IV kota. Berikut isi pada naskah:

"kalo apa-apa hal keuntungan atawa kerugian dalam laras IV kota sama juga kami hakim nan bertiga

Jika apapun keuntungan atau terjadi kerugian dalam laras IV kota maka hakim yang bertiga berbagi keuntungan jika suatu ketika terjadi kerugian dan begitupun sebaliknya. 
Poin kedelapan pada naskah undang-undang adat bersanding syara' ini membahas mengenai pendirian imam dan wakil di laras IV kota. Dibawah ini adalah isi pada naskah:

"Kadelapan, adapun pakkan di kotta, toeha orang IV kota nan poenja, sebab itoe krana saja nan djadi imam dalam laras IV kota, djadi saja nan mandirikan wakil jang akan mandrabih dalam pakan itoe, dan adat pandrabih ialah saja dengan wakil saja nan poenja bahagian, tiada tjampoer toeanku laras dan toeanku djaksa krana adat jang tetab terpakei selamanja tialiput di hoedjan dan tiada lekang dipanas"

Adapun orang yang berasal dari IV kota yang kaya oleh karenanya yang menjadi imam dalam laras IV kota, kemudian memilih wakil yang akan mandrabih dan adat pandrabih dalam pakan itu sehingga wakil saja yang punya bagian, tidak ada ikut campur tuanku Laras dan toeanku Djaksa karena adat yang tetap ada dan terpakai selamanya yang tidak luput dengan hujan dan tidak lekang panas. ${ }^{36}$

Berdasarkan isi dari Undang-undang Sumatera Barat bagian bersyanding syara, isi Undang-undang tersebut masih mengikuti peraturan yang ada dalam agama Islam. Hal ini menunjukkan bahwa Pemerintah Hindia Belanda membolehkan syariat atau hukum islam digunakan dan diberlakukan kepada masyarakat. Pemerintah tidak melarang hukum Islam digunakan. Hanya saja, hukum Islam yang digunakan hanya mengenai Zakat, Fitrah, Nikah serta pelaku halal dan haram.

\section{Perbedaan antara Undang-undang nan 20 dengan Undang-undang Sumatera Barat}

Tabel 4 Perbedaan secara umum antara Undang-undang nan 20 dengan Undang-undang Sumatera Barat

\begin{tabular}{|l|c|c|c|c|}
\hline No & Perbedaan & Undang- & Undang- & Keterangan \\
& & undang nan 20 & $\begin{array}{c}\text { undang } \\
\text { Sumatera }\end{array}$ & \\
& & & Barat & \\
\hline
\end{tabular}

\footnotetext{
${ }^{36}$ Manuskrip Drie Oendang-oendang's Sumatra's Kesthust
} 


\begin{tabular}{|c|c|c|c|c|}
\hline 1. & $\begin{array}{l}\text { Berdasarkan } \\
\text { jumlah BAB }\end{array}$ & $\begin{array}{l}\text { Terbagi } \\
\text { menjadi 2: UU } \\
\text { nan salapan } \\
(8), \text { UU nan } \\
\text { duo baleh (12) }\end{array}$ & $\begin{array}{l}\text { Terbagi } \\
\text { menjadi 3: UU } \\
\text { adat dalam } \\
\text { Nagari, UU } \\
\text { perkara } \\
\text { pembunuhan, } \\
\text { UU adat } \\
\text { bersanding } \\
\text { syara }\end{array}$ & $\begin{array}{l}\text { Pada kedua UU } \\
\text { tersebut yang } \\
\text { lebih banyak } \\
\text { memuat isi adalah } \\
\text { pada UU sumatera } \\
\text { Barat }\end{array}$ \\
\hline 2. & $\begin{array}{l}\text { Berdasarkan } \\
\text { pengaturan } \\
\text { kepemimpinan }\end{array}$ & Tidak ada & $\mathrm{Ada}^{37}$ & $\begin{array}{l}\text { UU nan } 20 \text { hanya } \\
\text { menjelaskan } \\
\text { mengenai tindak } \\
\text { kejahatan } \\
\text { seseorang dalam } \\
\text { suatu nagari }\end{array}$ \\
\hline 3. & $\begin{array}{l}\text { Berdasarkan } \\
\text { definisi } \\
\text { kejahatan }\end{array}$ & $\begin{array}{l}\text { Perlakuan } \\
\text { pembunuhan, } \\
\text { pencurian, } \\
\text { kekerasan dan } \\
\text { perlakuan Zina }\end{array}$ & $\begin{array}{l}\text { Perkara } \\
\text { Pembunuhan }\end{array}$ & $\begin{array}{l}\text { UU nan } 20 \text { secara } \\
\text { keseluruhan } \\
\text { mengenai } \\
\text { kejahatan, } \\
\text { sedangkan UU } \\
\text { sumatera barat } \\
\text { mengenai, } \\
\text { kepemimpinan, } \\
\text { pembunuhan, adat } \\
\text { bersanding syara. }\end{array}$ \\
\hline 4. & $\begin{array}{l}\text { Berdasarkan } \\
\text { keringanan } \\
\text { terhadap } \\
\text { Terdakwa }\end{array}$ & Tidak ada & $\mathrm{Ada}^{38}$ & $\begin{array}{l}\text { UU nan } 20 \text { hanya } \\
\text { mengenai definisi } \\
\text { kejahatan dan } \\
\text { alasan } \\
\text { penangkapan }\end{array}$ \\
\hline
\end{tabular}

\footnotetext{
${ }^{37}$ Lihat Undang-undang Adat dalam Nagari poin 1-4.

38 Tabel Error! Main Document Only. Klasifikasi doensanak yang membantu terdakwa
} 
\begin{tabular}{|l|l|l|l|l|}
\hline & & & & terdakwa. \\
\hline
\end{tabular}

Sumber: Tabel ini diolah dari Manuskrip Drie Oendang-oendang's Sumatra's Kesthust dan A. Irzal Rias, 2014, "Customary Crime Settlement Based on the Adat Law of Minangkabau: A Criminological Study”, Academic Research International, Vol. 5(2). Hlm. 438.

\section{Berakhirnya Undang-undang Sumatera Barat}

Kemungkinan berakhirnya undang-undang Sumatera Barat pada tahun 1862 ini karena ketika itu pemerintahan Belanda telah menerapkan Cultur Stelsel terhadap seluruh masayarakat.meskipun Undang-undang Sumatera Barat tetap berakhir bukan berarti berhenti.karena Undang-undang ini berasal dari hukum adat yanh telah lama melekat pada masyarakat Minangkabau.

Kedudukan Belanda di tanah minangkabau telah melakukan banyak perubahan, salah satunya dalam hal perekonomian khususnya di bidang perkebunan kopi, sehingga sistem tanam paksa itu diperintahkan oleh A.V Michiels, Gubernur Sumatera Barat. pada tahun 1847 Gubernur Sumatera Barat tersebut mewajibkan seluruh masyarakat untuk menanam pohon kopi dan kemudian menghantarkan seluruh hasilnya ke gudang-gudang kopi Pemerintah Belanda yang telah disediakan dibeberapa tempat tertenntu. ${ }^{39}$

Oleh sebab itu pada tahun 1859 perekonomian di Sumatera barat di bawah kekuasaan Pemerintah Belanda semakin berkembang pesat dengan meningkatnya volume perdagangan kopi serta harga yang semakin tinggi. ${ }^{40}$

Sehingga sumatera barat atau tanah minangkabau otomatis menjadi pusat perekonomian kopi yang melambung tinggi keberhasilannya, inilah yang menjadi alasan bahwa undang-undang sumatera barat berlaku hingga tahun 1862 sebab sumatera barat tergeser dengan UU Perekonomian yang berlaku pada masyarakat ketika itu dan masyarakat focus melaksanakan tanam paksa kopi yang diperintahkan oleh Pemerintahan Belanda. ${ }^{41}$

${ }^{39}$ Albani Suryani, Mestika Zed, and Etmi Hardi, "Studi Komparatif: Sistem Tanam Paksa Sumatera Barat Dengan Jawa," Jurnal Kapita Selekta Geografi 4, no. 13 (2019). 13

${ }^{40}$ Suryani, Zed, and Hardi. 13

${ }^{41}$ Suryani, Zed, and Hardi. 13 


\section{Kesimpulan}

Undang-undang Sumatera Barat ditulis dalam bentuk naskah dengan jumlah 33 halaman, menggunakan tulisan latin dan berbahasa Melayu. Undang-undang ini ditulis pada tahun 1837-1862 di tanah Minangkabau. UU Sumatera Barat ini memuat 3 poin besar didalamnya yaitu:

1. Undang-undang hukum adat dalam Nagari, UU ini memuat 8 poin pada poin 1-4 membahas mengenai kepemimpinan seorang imam, penghulu dalam suatu wilayah/kota. kemudian pada poin 5-8 mengenai usaha-usaha dalam penyelesaian suatu perkara yang terjadi pada suatu wilayah/kota. UU ini struktur pemerintahannya melihat pada Belanda padahal isinya pemerintahannya adalah masyarakat Minangkabau. 2. Undang-undang Perkara Pembunuhan, membahas mengenai hal-hal perkara seseorang yang melakukan pembunuhan, pada bagian UU ini terdapat 3 pasal didalamnya tetapi memuat isi yang lebih banyak sebab dilengkapi dengan penjelasan bagi para doensanak (saudara) yang akan membantu meringankan hukuman terdakwa. Hukum yang diterapkan pada UU ini adalah berdasarkan Adat Minangkabau tetapi sesuai juga pada syari'at islam karena didalamnya ada hukum kitsas dan diyat. 3. Undang-undang Adat bersanding Syara', UU ini mempunyai 8 poin didalamnya membahas mengenai Zakat, Fitrah, Nikah, Talak dan halal serta haram. UU ini secara keseluruhan isinya berdasarkan pada syari'at Islam. 


\section{References}

Abubakar, Lastuti. "Revitalisasi Hukum Adat Sebagai Sumber Hukum Dalam Membangun Sistem Hukum Indonesia." Dinamika Hukum 13, no. 2 (2013).

Ali, Ahmad. Menguak Tabir Hukum. Jakarta: Kencana, 2015.

Ferlan, Niko. "Konsep Nikah Sepupu Dalam Presfectif Adat Minangkabau

Dan HukumIslam Studi Kasus Luhak Agam Lubuk Basung Sumatera Barat (Antara Syari'ah Dan Adat)." UIN Sultan Syarif Kasir Riau, 2016.

Hamid, Abd Raahman. Pengantar Ilmu Sejarah. Yogyakarta: Ombak, 2011.

Joustra, M. Minangkabau Overzicht Van Land, Geschiedenis En Volk. Gravenhage: Martinus Nijhoff, 1923.

"Manuskrip Drie Oendang-Oendang's Sumatra's Kesthust," n.d.

Maryelliwati. Sastra Minanggkabau Dan Penciptaan Sebuah Karya. Padang:

Institut Seni Indonesia Padang Panjang, 2016.

Rahmat, Aulia. "Reaktualisasi Nilai Islam Dalam Budaya Minangkabau Melalui Kebijakan Desentralisasi.” El-Harakah 13, no. 1 (2011).

Rias, A. Irzal. "Customary Crime Settlement Based on the Adat Law of Minangkabau: A Criminological Study." Academic Research International 5, no. 2 (2014).

Suryani, Albani, Mestika Zed, and Etmi Hardi. "Studi Komparatif: Sistem Tanam Paksa Sumatera Barat Dengan Jawa." Jurnal Kapita Selekta Geografi 4, no. 13 (2019).

Susanto, Budi. Ge(Mer)Lap Nasionaltas Postkolonial. Yogyakarta: Kanisius, 2008.

Taher, Munir. "Silungkang Dalam Sejarah," 2007. munirtaher.wordpress.com.

Toeah, Datoek. Tambo Alam Minangkabau. Bukit Tinggi: Pustaka Indonesia, n.d.

Witrianto. “Agama Islam Minangkabau.” 2010. 